\title{
Performance Appraisal and Bonus Calculation for Warehouse Employees
}

ALEKSANDRA N. NOVKOVIĆ, University of Belgrade,

Faculty of Transport and Traffic Engineering, Belgrade UDC: 331.101.39:621.796

MILAN M. ANDREJIĆ, University of Belgrade, DOI: 10.5937/tehnika2006790N

Faculty of Transport and Traffic Engineering, Belgrade

MILORAD J. KILIBARDA, University of Belgrade,

Faculty of Transport and Traffic Engineering, Belgrade

The development of global supply chains, market liberalization, and new business trends have contributed to creating more competition in the market and increasing demand. Logistics companies strive to generate revenue by providing services of a higher scope and level of quality, while cost minimization is often associated with a system of calculating salaries and employee benefits. The fluctuation of workers is one of the current problems faced by a large number of companies, so the development of a system that will improve conditions and motivate workers is very important. The paper proposes a model for evaluating work performance and calculating bonuses for employees in the warehouse. The model considers the main performance indicators that refer to work engagement in terms of the number of picked items and presence at the workplace. The sensitivity analysis of the model established the convenience and universality of the application.

Key words: work performance, variable payments, bonus, incentive system, working conditions

\section{INTRODUCTION}

Modern business conditions are increasingly contributing to the creation of challenges facing logistics companies. Increasing the scope of requirements, availability, flexibility, and quality of service provided are some of the consequences of new trends. Considering that the fourth industrial revolution has an impact on the development of information systems and the degree of process automation, in most business segments of logistics companies, people are still a key resource for achieving goals and performance. One of the main goals in business is to generate as much revenue as possible with minimal investment, so it often happens that companies reduce costs in the wrong way and thus directly affect employee fluctuation, which is one of the major problems facing the logistics sector. By establishing an appropriate payment and rewarding system employee productivity increases and costs can also be reduced. It is necessary to apply a system of

Author's address: Aleksandra Novković, University of Belgrade, Faculty of Transport and Traffic Engineering, Belgrade, Vojvode Stepe 305

e-mail: aleksandranovkovic1@gmail.com

Paper received: 05.08.2020.

Paper accepted: 11.12.2020. incentives which basically consists of monetary compensations or non-financial methods that could improve working conditions. Good communication and cooperation with employees, building trust, and recognizing the need for both can lead to a "win-win" situation. In addition to the introduction and conclusion, the paper consists of three parts, where the first describes the segments related to labor productivity, such as the organization of working time and overtime work. Incentive programs and variable payment systems are also included in this point, while the second and third parts refer to evaluating the performance of the warehouse employees and the model improvements through sensitivity analysis.

\section{PROBLEM REVIEW}

Productivity can be presented as a general measure of economic efficiency which implies achieving maximum results with minimum investments, through increasing the volume of production or work performance. The efficiency of the functioning of logistics systems is actually reflected in the efficient operation of all its subsystems, which consist of numerous processes with varying degrees of complexity [1].

Labor productivity is usually defined as the ratio of the volume of production/services and inputs. The 
inputs can relate to time, skills, labor, etc. There are advantages and disadvantages associated with the various input measures used in the calculation of labor productivity. The total number of working hours is the most appropriate size that describes the workforce because the number of employees does not reflect changes in terms of average working hours - overtime, absence from work, and so on, which directly affects performance. Competitive pressures, the complexity of customer requirements, and the company's desire to increase the degree of reliability and flexibility often lead to extensive overtime work. Increased demands for work on all days of the week are a reality of progress towards ,24/7“ trends. Such requirements for wide availability, variable work schedule, „duty“ and availability in a very short time are among the most unfavorable modern working conditions due to significant disruptions and negative consequences [2]. Managing and planning working hours is one of the key segments of every company's successful business. Adaptability and quick responses to user requests have caused that the fixed working hours change during the week and to strive for new forms of working hours (work in shifts, shortening the working week, on-call duty, etc.). A large number of studies and researches conducted on this topic indicate the principles of flexibility, which also affect the improvement of the use of time resources [5]. Motivating and rewarding employees is an important aspect of a good work organization. Incentive programs can create large savings and their definition and implementation within the business of different sectors of logistics companies can increase quality, staff satisfaction, and improve performance. When creating such programs, the balance, measurability, inclusiveness, comparison and transparency should be considered [3].

In practice, financial rewards (bonuses, profit sharing, etc.) are most often used, but other methods can also be very productive and useful, such as benefits that improve the quality of life, education and training, preferential choices, etc. Figure 1 shows the model of the reward system [4].

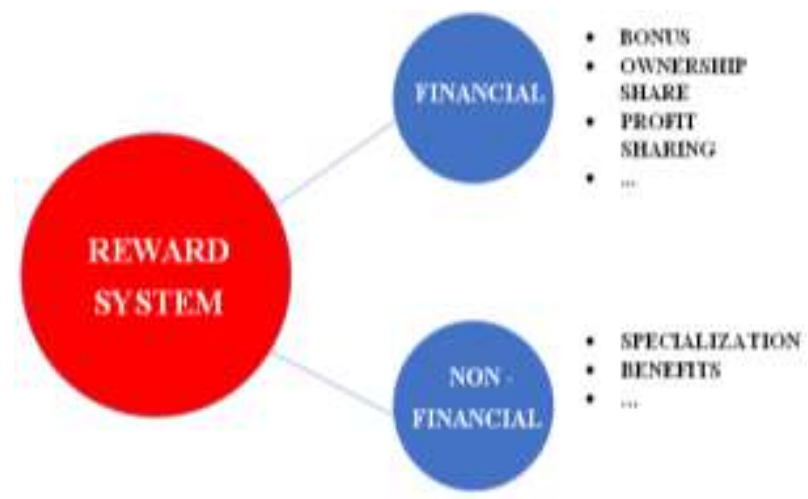

Figure 1 - Reward system
The structure of compensation and financial rewards contains two basic elements [7]. Fixed salary also known as a basic salary, that does not vary according to the work or results achieved by the worker. It is determined by the general philosophy and structure of the payment systems represented in the organization. Variable salary changes directly with the level of performance or results achieved by employees. It can be short-term or long-term depending on the goals, but it must be earned each time.

In addition to the policy and internal organization of the company, the systems of payment and evaluation of employees' work are directly related to the concept of labor market flexibility, which refers to the ability to adapt and respond to changing economic conditions [7]. In recent years, a trend has been observed, especially in the private sector, which links rewards to performance, trying to improve the achievement of organizational goals. Such compensation creates confidence among employees that a good performance will lead to a higher total salary, minimize negative consequences, or exceed defined goals. In fact, a variable salary is considered as a mechanism for reconciling the interests of employees with the interests of the employer.

\section{EVALUATING THE PERFORMANCE OF WAREHOUSE EMPLOYEES - CASE STUDY}

This chapter observes a case study that describes a business example from the logistics company that operates on the Serbian market, and due to data protection, its name was not stated. This case study may have an impact during the analysis and the development of solutions that would improve the business productivity of a company.

The system of rewarding employees that work in a warehouse implies defining the criteria, the procedure for realization, the method of calculation, and payment of bonuses. The bonus is paid in cash and calculated for a calendar month, starting from the first and ending with the last day of the calendar month. In order for employees to be entitled to the bonus calculation, it is necessary to be present at work at least $90 \%$ of the working days during the calendar month. Absence of employees due to the use of annual leave and/or temporary incapacity for work due to an injury at work does not negatively affect the calculation of the required number of working days for the bonus. Models for bonus calculation depend on the segments of the goods in the warehouse. If the goods belong to categories I and II, the method of calculating the bonus depends on the realized turnover in the warehouse during the calendar month, calculated according to the purchase value of the goods. More precisely, $0,03 \%$ of the realized turnover is divided by the number of 
employees and calculated in proportion to the number of working days. Category I refers to the office supplies and consumable materials, while II includes non-food products such as clothing, footwear, household equipment, appliances, etc. Other segments are: without a temperature regime, cold regime, small units, fruits and vegetables, fresh meat, household chemicals and cosmetics, wholesale [6].

In that case, the calculation of bonus is determined by the number of picked items by segments of goods, which is reduced by the values of errors in the picking process. For each category of goods, there is a defined daily average, and for each item realized above the defined level, there is a determined price in the amount of 6 monetary units. During the calendar month, the minimum number of items that the employee should accomplish is defined, with the possibility of comments - clear and precise arguments in relation to the objectivity and achievability of the set goals. Errors in the picking process are determined by the referents for the control of exits, during the shipment of goods and during the control of complaints from retail facilities. All these criteria for calculating the bonus are recorded in the WMS.

$$
B=N I O N * N W D * V I O N
$$

B - bonus;

NION - the number of items over the norm;

NWD - the number of working days;

VION - the value of item over the norm.

The number of items above the norm is directly related to the average of items on a daily basis, and it is calculated as follows:

$$
N I O N=A P I-N
$$

API - the average of picked items per day;

$\mathrm{N}$ - the norm.

In order to determine the average of items on a daily basis, it is first necessary to reduce the total number of items by the value of generated errors during operation and divide with the number of working days.

$$
A P I=(T N I-(N E * E V)) / N W D
$$

TNI - total number of items;

$\mathrm{NE}$ - the number of errors;

$\mathrm{EV}$ - the error value.

Based on the report on employee performance in the relevant month of 2019, which concerns performance and bonus calculation, it can be concluded that there are differences depending on the segment of goods and the category of warehouse in which employees worked. In the relevant month, the bonus was paid to employees in the warehouse sector for fruits and vegetables, goods in the cold regime, and for the categories I and II. The realized bonus for the following categories of goods was [6]:

- Category I - 10.386 m.u.;

- Category II - 35.522 m.u.;

- Fruits and vegetables - 144.936 m.u.;

- Cold regime - 13.380 m.u.

Employees in other sectors of the warehouse didn't reach the necessary norms for the bonus. Warehouse sectors in which employees didn't earn a bonus, but had in both categories (number of picked items and the required number of working days) one or more fulfilled norms, are household chemicals and cosmetics and wholesale. For other categories of goods, it is characteristic that the employees either did not have a good work performance (smaller units) or a sufficient number of days to calculate the bonus (without temperature regime and fresh meat), which is shown in Table 1.

So, workers in the warehouse sectors for smaller units and wholesale in the relevant month of 2019 had the worst performance in terms of the number of picked items. That number was significantly lower than the predicted level, and it is good to consider the objectivity of the defined goal. The decision of changing the norm is based on the analysis of work performance over a longer period of time, but this indicator certainly shows employees inefficiency and should be taken into account.

Table 1. Fulfillment of conditions for bonus

\begin{tabular}{|l|l|l|l|}
\hline $\begin{array}{l}\text { CATEGORY OF } \\
\text { GOODS }\end{array}$ & $\begin{array}{l}\text { Norm } \\
\text { (number } \\
\text { of items) }\end{array}$ & $\begin{array}{l}\text { Number } \\
\text { of } \\
\text { working } \\
\text { days (\%) }\end{array}$ & $\begin{array}{l}\text { Number of } \\
\text { picked } \\
\text { items }(\%)\end{array}$ \\
\hline $\begin{array}{l}\text { Without a temp. } \\
\text { regime }\end{array}$ & 580 & 0 & 44,44 \\
\hline Fresh meat & 380 & 0 & 83,33 \\
\hline $\begin{array}{l}\text { Fruits and } \\
\text { vegetables }\end{array}$ & 240 & 56 & 60 \\
\hline Cold regime & 530 & 7,14 & 43 \\
\hline HC and cosmetics & 510 & 12,50 & 25 \\
\hline Small units & 450 & 66,66 & 0 \\
\hline Wholesale & 400 & 57,14 & 1,78 \\
\hline
\end{tabular}

\section{SENSITIVITY ANALYSIS AND MODEL IMPROVEMENT}

The aim of this paper is to test and analyze the sensitivity of the model due to changes in defined categories that directly affect the calculation of bonus and to determine possible scenarios and improved the existing system. Considering the existing distribution of bonuses in the company, it can be concluded that the change of the previously mentioned items affects only 
the bonus of those employees who reached the defined levels. If the employees do not accomplish the minimum number of days that it is necessary to spend at work, the bonus certainly cannot be calculated and no oscillations will be noticed. However, for all employees who have achieved the required number of picked items, it will be assumed that the norm related to the number of working days is reached.

\section{The error value}

Picking errors occur frequently and affect workflow efficiency. In this case, the value of the error is expressed in the number of items and if it decreases, the bonus may increase. The calculation, which is now based only on the required number of picked items, directly increases the number of employees who would receive compensation. Accordingly, the fresh meat sector has the best results because $80 \%$ of them meet the defined requirement. Efficiency in work is certainly directly related to the number of mistakes they made. Specifically, a decrease in the value of one error by $50 \%$ (from 80 to 40 ) affects the growth of the total bonus by $2,6 \%$. This is precisely the consequence of a small number of errors, which does not contribute to oscillations in the amount of the bonus. In the warehouse where the picking of fruits and vegetables is realized, the employees also achieved good results in terms of picked items (60\% of them) and the reduction of the error value by $50 \%$ affects the growth of the total bonus by $5,6 \%$. So, it can be noticed that the employees made a slightly higher number of mistakes in relation to the previously mentioned category. Potentially, $44 \%$ of them would get a bonus, and with the same decrease in the value of the error of $50 \%$, in the observed category, the growth of the bonus would be $12,95 \%$. This is a direct consequence of the number of errors, so the decrease in the value of one was directly reflected in the bonus. The picking of goods that are in the cold regime was successfully realized by $43 \%$ of the total number of employees, and the variation in the value of the error affects the increase in growth by about $4,77 \%$ (Table 2).

Table 2. Bonus - variation of the error value

\begin{tabular}{|c|c|c|c|c|}
\hline \multirow[b]{2}{*}{$\begin{array}{l}\text { CATEGORY } \\
\text { OF GOODS }\end{array}$} & \multicolumn{4}{|c|}{ BONUS (m.u.) } \\
\hline & $\begin{array}{l}\text { The } \\
\text { error } \\
\text { value } \\
(80)\end{array}$ & $\begin{array}{l}\text { The } \\
\text { error } \\
\text { value } \\
(40)\end{array}$ & $\begin{array}{l}\text { Savings } \\
\text { (m.u.) }\end{array}$ & $\begin{array}{l}\text { Savings } \\
(\%)\end{array}$ \\
\hline $\begin{array}{l}\text { Without a } \\
\text { temp. regime }\end{array}$ & 98.202 & 110.922 & 12.720 & 12,95 \\
\hline $\begin{array}{l}\text { Fruits and } \\
\text { vegetables }\end{array}$ & 154.254 & 162.894 & 8.640 & 5,60 \\
\hline Cold regime & 145.800 & 152.760 & 6.960 & 4,77 \\
\hline Fresh meat & 110.880 & 113.760 & 2.880 & 2,60 \\
\hline
\end{tabular}

Employees in other sectors of the warehouse had a poor performance in terms of the number of picked items (specifically household chemicals and cosmetics $-25 \%$, wholesale about $2 \%$, and in the sector of smaller units employees did not achieve a defined norm - 0\%), and therefore variation the error value would not make sense.

\section{The value limit of the norm}

The limit value of the norm represents the number of items on a daily level and it differs from the segments of goods. It is necessary to find a balance and establish a level that is not unattainable but at the same time not easily achievable. Changes in the limit value of the norm directly affect the increase of the total bonus because a larger number of employees actually reaches the required level. In the following work, it will be analyzed how the reductions of $10 \%, 15 \%$, and $20 \%$, affect the bonus. In the warehouse sector for picking goods that do not require a certain temperature regime and where the norm of the item is 580 , with the mentioned reductions, that number has values of 522 , 493, and 464, respectively. In the first case, the number of employees who are entitled to the bonus increased by about $11 \%$, while the total value of the bonus increased by $54 \%$. In fact, only 2 new workers met the condition in the number of items, but for the others, the number of items over the norm automatically increased, as well as the bonus itself. It is similar to the reduction of the value of the limit norm of $15 \%$ and $20 \%$, while in the second case about $72 \%$ of them are entitled to a bonus, which is significantly higher compared to the initial situation.

On the picking of goods in the cold regime, $43 \%$ of them achieved a total bonus of 145.800 m.u. A decrease in the number of the defined norm of $10 \%$ resulted in an increase in the total bonus by about $36 \%$, and a decrease of $15 \%$ contributed to an increase in the number of employees who achieved the required number of items above the norm to about $64 \%$, and the total bonus increased by $57 \%$. As in the previous case, the biggest difference is noticed when the limit value of the item is reduced by $20 \%$. The total bonus then amounts to 260.718 m.u. which represents an increase of about $78 \%$.

Performance within the segment of goods related to smaller units, looking at the initial situation is very poor. Actually, none of the employees managed to reach or exceed the defined norm of items. Employees in the warehouse sector intended for the picking of fruits and vegetables generally achieved the best performance.

The reductions in the threshold value had an impact on the increase of the already existing bonus rather than on the increase in the number of employees 
who are entitled to it. The defined norm of 240 items with a reduction of $10 \%, 15 \%$, and $20 \%$ increased the total bonus by about $31 \%, 48 \%$, and $66 \%$ respectively. It is similar with the category of goods related to fresh meat, where $80 \%$ of employees who earned the bonus did not change with the reduction of the limit value of the norm, but the total bonus increased by about $34 \%$, $52 \%$ and $69 \%$, which is significant. The last 2 categories refer to household chemicals and cosmetics and wholesale. In the first, employees achieved relatively low performance, where only $25 \%$ of them reached the required level, but the reduction of the limit value of the norm had a significant impact on the increase in bonuses. A concrete decrease of $10 \%$ contributed to the increase of the bonus by $54 \%$, a decrease of $15 \%$ increased the bonus by about $90 \%$, and a decrease of $20 \%$ even more, more precisely over $100 \%$. Wholesale had the largest number of errors generated by employees (up to 68), so the direct consequence is a very small number of those who managed to get a bonus, more precisely only 1 of the 56 , which is not even $2 \%$. All the above changes are shown in Table 3.

Table 3. Bonus - variation of the limit norm

\begin{tabular}{|l|l|l|l|l|l|l|l|l|}
\hline \multirow{2}{*}{$\begin{array}{l}\text { CATEGORY OF } \\
\text { GOODS }\end{array}$} & \multirow{2}{*}{ Initial state } & \multicolumn{2}{l|}{ REDUCTION OF THE LIMIT NORM (\%) } & \multicolumn{4}{l|}{ BONUS INCREASE (\%) } \\
\cline { 2 - 10 } & & 10 & 15 & 20 & 10 & 15 & 20 \\
\hline $\begin{array}{l}\text { Without a temp. } \\
\text { regime }\end{array}$ & 98.202 & 152.136 & 181.992 & 216.864 & 54,92 & 85,32 & 120,83 \\
\hline Cold regime & 145.800 & 199.248 & 229.518 & 260.718 & 36,66 & 57,42 & 78,82 \\
\hline Small units & 0 & 0 & 4.494 & 10.566 & 0,00 & 0,00 & 0,00 \\
\hline Fruits and vegetables & 154.254 & 203.034 & 228.804 & 256.548 & 31,62 & 48,33 & 66,32 \\
\hline Fresh meat & 110.880 & 149.184 & 168.336 & 187.488 & 34,55 & 51,82 & 69,09 \\
\hline HC and cosmetics & 17.256 & 26.742 & 32.928 & 44.634 & 54,97 & 90,82 & 158,66 \\
\hline Wholesale & 22.812 & 24.192 & 31.092 & 33.852 & 6,05 & 36,30 & 48,40 \\
\hline
\end{tabular}

\section{The value of item over the norm}

The value of the calculated bonus, in addition to the number of items that employees reached over the norm, is also affected by the unique price of the item. In this case, it is 6 m.u. and changes in its value can certainly reduce/increase the bonus. For analyzing the sensitivity of the existing model, the value of an item over the norm changed to 5,7 , or 8 m.u.. In case of a decrease / increase of the initial value by 1 m.u. the total bonus is reduced/increased by $16,67 \%$, while due to the increase of 2 m.u. there is an increase in bonuses by about $33 \%$. This applies to all segments of warehouses and categories of goods since the principle of calculation is the same.

\section{The method of calculation}

Depending on the segment of goods, the approach on the basis of which the fee is determined also differs. The bonus within categories I and II directly depends on the realized turnover and is calculated as a percentage $(0,03 \%)$, while in other cases there is a defined norm in the number of picked items as well as the value of the item over the norm. In accordance with the sensitivity analysis of the model, it is necessary to determine whether the change in the approach to calculating bonuses in certain categories leads to differences, as well as whether the combination of both is more acceptable than the existing way. The company determines and approves the number of bonuses that can be paid to employees on a monthly basis, and in this case, it was 900.000 m.u.. Given that the warehouse is divided into nine sectors, it will be assumed that the total value is distributed and that the maximum approved bonus per sector is about 100.000 m.u.. Analyzing the current situation, it can be seen that in some categories this number was much lower or higher, which certainly depends on the performance and turnover.

In the category of warehouses for the goods that are not in a special temperature regime, the realized bonus according to the initial state was $98.202 \mathrm{~m} . \mathrm{u}$. and the method of calculation was based on the number of picked items. Therefore, this value fits into the previously defined norm of the maximum bonus, and if a different approach was applied, which is based on the realized turnover (560.000.000 m.u.), that number would be 168.000 m.u. which exceeds the predicted value. In fact, reducing the percentage of the bonus from $0,03 \%$ to $0,0175 \%$ would also affect the reduction of the value of the total bonus, which in that case would amount to $98.000 \mathrm{~m}$.u, so the maximum amount of 100.000 m.u. would not be exceeded. As for the category of goods related to fresh meat, the difference in the calculation of bonuses between the first and second approach is 5.580 m.u. which does not represent a large deviation. In particular, the total bonus 
according to the current situation is 110.880 m.u. while the calculation based on the turnover $(351.000 .000$ m.u.) has a value of 105.300 m.u. In the first case, an increase in the number of picked items required on a daily basis by $5 \%$ would directly affect the reduction of the bonus value below the defined norm (from 110.880 m.u. to 91.728 m.u.), as well as a decrease in the value of the item over the norm (with $6 \mathrm{mu}$ to 5 m.u.), whereby the value of the total bonus would then be 92.400 m.u.

The total turnover in the relevant month for fruits and vegetables was $350.000 .000 \mathrm{~m} . \mathrm{u}$. and the application of the calculation according to the percentage would affect the value of the total bonus and reduce the excess of about 5.000 m.u.. Employees in the warehouse sector, where goods are stored in cold mode earned a bonus of 145.800 m.u. based on a calculation of the number of items.

Exceeding the envisaged maximum bonus could be reduced by increasing the established norm in the number of picked items. For the segments of goods that include smaller units and chemicals and cosmetics, total turnover was 290.000.000 m.u. The value of the calculated bonus was 87.000 m.u. and in order to increase that amount to $100.000 \mathrm{~m}$.u. it is necessary to increase the percentage from $0,03 \%$ to $0,034 \%$. So, that would mean that the amount of the maximum bonus now refers to the value of 50.000 m.u. observing these two categories individually.

Taking into account the very poor work performance when it comes to smaller units, it can be concluded that in that case, the employees would realize greater benefits if the bonus was calculated as a percentage of turnover.

The mentioned 50.000 m.u. would be distributed equally, so that on average each of the 6 workers would earn a bonus of about 8.216 m.u.. Table 4 shows the total turnover by category of goods as well as changes in the bonus that result from reducing the percentage of turnover.

Combining the bonus calculation approach, for each category of goods individually, conditions changes in defined norms. By respecting the number of items, but also the realized turnover, a different distribution of the calculated bonus was obtained.

Actually, the idea is that all employees who have reached the required level of items automatically receive a bonus calculated according to the percentage of turnover, and depending on how much they have exceeded the norm, the reward is increased while keeping the value of the item above the norm of 6 m.u.. For each segment of the warehouse, the turnover and the number of employees are different, so the decrease/increase in the value of the established norms differs in order to fit the total approved bonus into the analysis of the assumed value of 100.000 m.u.. In the case of a category of goods stored without a temperature regime, the percentage of turnover was not changed, and based on the calculation, the amount of the bonus per employee was 9.400 m.u.. The condition that implied that the norm of 580 items was exceeded by a minimum of $20 \%$ was met by a total of 3 workers.

By summing up the bonus, a value of 98.000 m.u. was obtained which is in accordance with the previously mentioned condition of the total approved bonus. Employees in the fresh meat warehouse segment were charged a bonus with the item norm in the same way, but the value of the turnover percentage was reduced to $0,02 \%$. For the category of fruit and vegetable goods, the percentage of turnover had the same value as in the calculation for fresh meat, and each employee who met the norm in the minimum of items received 2.800 m.u.

However, due to the good work performance of the employees, the approach that respected $20 \%$ over the defined norm in terms of the number of items was increased to $35 \%$ because in the first case the total calculated bonus was around 140.000 m.u. which is certainly higher than the assumed 100.000 m.u..

For the storage of goods in the cold mode, the percentage of turnover is reduced from $0,03 \%$ to $0,027 \%$ and each employee with a met norm would receive 6.000 m.u.. According to the initial situation, it was necessary to reduce the required percentage.

In the case of segments of goods that include chemicals and cosmetics as well as smaller units, due to the generally poor performance of employees, the combination of this approach to calculating bonuses is not very important because only 2 of 8 workers earned a bonus (chemicals and cosmetics - they increase bonuses because have exceeded the set minimum of $10 \%$ over the norm), and there were no employees who earned the bonus in the sector of smaller units.

Table 4 shows the data related to the combination of bonus calculation approaches and in comparison with the previous way which respects only the percentage of realized turnover, it can be noticed that for each category of goods, except the last, the total bonus is closer to the assumed amount of 100.000 m.u. and that the distribution of funds in that regard is better.

A comparative presentation of the total amount of the calculated bonus is given in Figure 2 and differences can be observed in the initial state even after reducing the percentage of turnover (Bonus I) and the norm in terms of picked items (Bonus II). 
Table 4. Bonus calculation approaches

\begin{tabular}{|c|c|c|c|c|c|c|c|c|}
\hline \multirow[b]{2}{*}{$\begin{array}{l}\text { CATEGORY } \\
\text { OF GOODS }\end{array}$} & \multirow[b]{2}{*}{$\begin{array}{l}\text { TURNOVE } \\
\text { R (m.u.) }\end{array}$} & \multicolumn{4}{|c|}{ APPROACH I } & \multicolumn{3}{|c|}{ APPROACH II } \\
\hline & & $\begin{array}{l}\text { Percentage } \\
\text { of turnover } \\
\text { for bonus } \\
\text { calculation } \\
(\%)\end{array}$ & $\begin{array}{l}\text { BONUS } \\
\text { (m.u.) }\end{array}$ & $\begin{array}{l}\text { Reduced } \\
\text { percentage } \\
\text { of turnover } \\
\text { for bonus } \\
\text { calculation } \\
(\%)\end{array}$ & $\begin{array}{l}\text { BONUS } \\
\text { (m.u.) }\end{array}$ & $\begin{array}{l}\text { Reduced } \\
\text { percentage } \\
\text { of turnover } \\
\text { for bonus } \\
\text { calculation } \\
(\%)\end{array}$ & $\begin{array}{l}\text { Percentage } \\
\text { of picked } \\
\text { items } \\
\text { above the } \\
\text { norm }(\%)\end{array}$ & $\begin{array}{l}\text { BONUS } \\
\text { (m.u.) }\end{array}$ \\
\hline $\begin{array}{l}\text { Without a temp. } \\
\text { regime }\end{array}$ & 560.000 .000 & 0,03 & 168.000 & 0,0175 & 98.000 & 0,03 & 20 & 98.000 \\
\hline Fresh meat & 351.000 .000 & 0,03 & 105.300 & 0,028 & 98.280 & 0,02 & 20 & 99.580 \\
\hline $\begin{array}{l}\text { Fruits and } \\
\text { vegetables }\end{array}$ & 350.000 .000 & 0,03 & 105.000 & 0,028 & 98.000 & 0,02 & 35 & 98.184 \\
\hline Cold regime & 315.000 .000 & 0,03 & 94.500 & - & 94.500 & 0,027 & 10 & 98.286 \\
\hline $\begin{array}{l}\mathrm{HC} \text { and } \\
\text { cosmetics }\end{array}$ & \multirow[t]{2}{*}{290.000 .000} & \multirow[t]{2}{*}{0,03} & \multirow[t]{2}{*}{87.000} & \multirow[t]{2}{*}{0,034} & \multirow[t]{2}{*}{98.600} & \multirow[t]{2}{*}{0,034} & 10 & \multirow[t]{2}{*}{98.600} \\
\hline Small units & & & & & & & - & \\
\hline
\end{tabular}

For the category of goods related to fruits and vegetables as well as the cold regime, exceeding the assumed amount of the approved bonus is about $50 \%$. In the segments of household chemicals and cosmetics and smaller units, employees would earn higher income compared to the initial state. In the remaining warehouse sectors, the initial bonus was approximately 100.000 m.u.

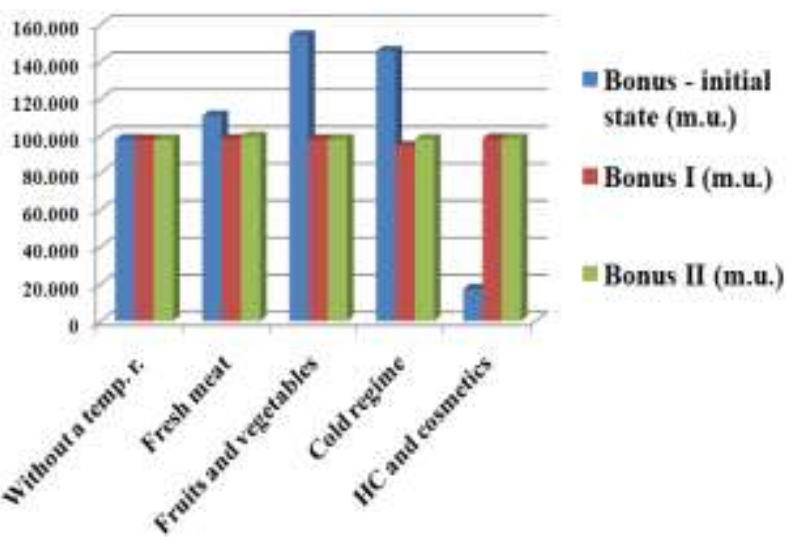

Figure 2 - A comparative review of the calculated bonus

\section{CONCLUSIONS}

The role of the performance of employees in achieving organizational goals has long occupied the attention of the management of logistics companies. In fact, the establishment of an adequate system of rewards and incentives can affect the productivity of work. Human resources and good work organization actually contribute to the efficient fulfillment of defined goals. Increasing competition and changing market conditions require companies to invest in every business segment, and despite all the technologies and innovations, intellectual capital and workforce are still the most important. All this gives rise to the creation of overtime work and an imbalance of business activities. Employees often leave the company because of the lack of choice.

In order to retain workers, companies need to implement an appropriate system for evaluating and identifying the performance of each employee, team, or the entire organization, and to apply adequate rewards. Conducting case studies, research, and comparisons with the best in practice have great importance and can certainly contribute to the improvement of the existing situation.

So, the success of the entire organization is a consequence of the success of all its subcategories, processes, activities, and individuals, whose performance is constantly monitored, improved, and rewarded. It is necessary to establish a system of measuring and calculating bonuses that are not unattainable but also not easily achievable.

The variation of certain items that directly affect bonus shows the dependency between the degree of fulfillment of the required level and defined norms. In future research it is important to use different approaches and methods like DEA that provide information on the realization of the processes and give the organization the opportunity to improve them.

It is also important that each company defines a strategy (model) that would allow employees to directly express their opinions and arguments in relation to the objectivity and reality of the defined norms and criteria. Continuity in monitoring and measuring performance contributes to better organization and also improves employee performance. 


\section{Literature}

[1] Andrejić, M. Measuring Efficiency in Logistics, Military Technical Courier, Vol. 61, No. 2, pp. 84$104,2013$.

[2] Avery, C., Zabel, D. The flexible workplace: A sourcebook of information and research, Quorum Books, Westport, Connecticut, 2001.

[3] Hopkins, M. Introduction to Variable Pay, SARA Conference, Johannesburg, South Africa, 24-25 October 2013.

[4] Mendis, M. The Impact Of Reward System On Employee Turnover Intention: A Study On Logistics
Industry Of Sri Lanka, International Journal of Scientific \& Technology Research, Vol. 6, No. 9, pp. 67-72, 2017.

[5] Messenger, J. Working time and the future of work, International Labour Oranization: Research paper series, 2018.

[6] Novković, A. Normiranje učinka zaposlenih $u$ logističkim kompanijama, Master thesis, University of Belgrade, Faculty of Transport and Traffic Engineering, Belgrade, 2020.

[7] Rubery, J., Grimshaw, D. The Organization of Employment: an International Perspective, Palgrave Macmillan, Hampshire, New York, 2003.

\section{REZIME}

\section{NORMIRANJE UČINKA I PRORAČUN BONUSA ZAPOSLENIMA U SKLADIŠTU}

Razvoj globalnih lanaca snabdevanja, liberalizacija tržišta i novi trendovi u poslovanju doprineli su stvaranju veće konkurencije na tržištu i povećanju zahteva. Fluktuacija radnika je jedan od gorućih problema sa kojima se suočava veliki broj kompanija pa je razvoj sistema koji će unaprediti uslove $i$ motivisati radnike jako bitan. U radu je predložen model za vrednovanje radnog učinka i obračun bonusa zaposlenima na poslovima komisionara u skladištu. Model uzima u obzir glavne pokazatelje rada koji se odnose na ostvareni učinak u pogledu broja izdvojenih stvaki, kao i na prisutnost na radnom mestu. Analizom osetljivosti modela ustanovljena je pogodnost i univerzalnost primene.

Ključne reči: radni učinak, varijabilne naknade, bonus, sistem podsticaja, uslovi rada 